The 25th Lung Cancer Mass Screening Seminar

\title{
個別検診実施医療機関選定の問題点と対策
}

\author{
川西克幸 1 相馬 孝 1 四宮眞男 1
}

\section{Factors Involved in the Selection of Medical Institutions Conducting Individual Lung Cancer Screening}

Katsuyuki Kawanishi1; Takashi Soma1; Masao Shinomiya1

${ }^{1}$ The Suita Medical Association, Japan.

ABSTRACT - Objective. To design a more effective lung cancer detection system by studying the problems associated with selecting medical facilities that provide individual lung cancer screening. Methods. A survey was conducted at 154 institutions registered in Suita City as tuberculosis medical screening facilities, on whether they had implemented individual lung cancer screening that was started in 2008. We used questionnaires for checking medical instrument performance, radiographic conditions, materials used and so on. A final decision was then made by evaluating plain chest X-ray films at each medical institution. Results. We judged 120 medical institutions as compliant and accredited them. The remaining 34 medical facilities did not comply with conditions established by the Japan Lung Cancer Society, therefore they were refused accreditation. However, the radiographic image quality at accredited medical institutions was not sufficient. Conclusion. Continued instruction is required at medical institutions to take radiographic images that are suitable for diagnostic purposes. Furthermore, we believed that it is very important to design a prognosis evaluation system for efficient interpretations of radiograms to diminish the number of false-negative results.

KEY WORDS — Lung cancer screening, Quality assurance

(JJLC. 2012;52:956-960)

Reprints: Katsuyuki Kawanishi, The Suita Medical Association, 19-2 Deguchi-cho, Suita City, Osaka 564-0072, Japan (e-mail: jimu@suita-med.or.jp).

要旨一一目的. 個別肺がん検診実施医療機関を選定す るときの問題点を検討して，より有効な肺がん検診シス テムを設計する．方法．吹田市結核検診実施医療機関と して登録されていた 154 施設について, 平成 20 年度開始 の個別肺がん検診が実施可能であるか審査した．機器性 能, 撮影条件, 使用材料などをアンケートで確認した後, 各医療機関の胸部単純 $\mathrm{X}$ 線写真を評価して最終決定し た. 結果. 120 医療機関が適合していると判定され認定 施設となった. 残り 34 医療機関は日本肺癌学会で定める
条件に適合しないため不合格となった。しかし認定され た医療機関の X 線写真の画質もなお十分に満足できる ものではなかった． 結論. 撮影医療機関に対して診断に 適するX 線写真を撮影するための指導を続けていくこ とが必要である。それに加えて診断時の偽陰性を少なく するための効率的な読影, 判定システムを設計すること もまた重要であると考えている.

索引用語——肺がん検診, 精度管理
はじめに

大都市大阪市に隣接した住宅都市である吹田市は，そ
の地域特性から高い受診率を得るための施策として市内 の診療所などを健診実施の場所として, 各市民の誕生月 に健康診査, 各種がん検診, 結核検診, 骨粗しょう症検

1一般社団法人吹田市医師会.

大阪府吹田市出口町 19-2(e-mail: jimu@suita-med.or.jp).

別刷請求先：川西克幸, 一般社団法人吹田市医師会, $\overline{7} 564-0072$ 
診, 肝炎ウイルス検診などを同時に実施する方式で運営 してきた．そのため子宮がん検診, 乳がん検診, 大腸が ん検診は個別検診主体の運営となっていて, 平成 19 年度 の受診率で見るとそれぞれ $16.1 \%, 14.7 \%, 23.2 \%$ という 良好な成績であった。一方, 集団検診のみの運営をして いた肺がん検診と胃がん検診の受診率は $1.4 \%, 2.1 \%$ と いう結果であった．個別肺がん検診ができなかった理由 は, 多くの診療所の X 線機器の性能が肺がん検診を実施 する要件を満たさないため実施医療機関としての数が十 分に確保できなかったためであり，各診療所は結核検診 として胸部単純 X 写真を撮影することで対処してきた. ところが平成 19 年に結核予防法が廃止され感染症法に 集約化されたことにより, 結核検診の対象年齢が 65 歳以 上に制限されてしまった。 そのため 40 歳から 64 歳まで の市民の健康チェックとして胸部単純 X 線写真を撮影 するためには，個別肺がん検診を実施するしか選択肢が なくなった. そのため吹田市医師会と吹田市立保健セン ターが協議して検討を重ねた結果，吹田市で実施可能な 個別肺がん検診システムを設計して平成 20 年度から開 始することになった.

\section{1. 実施医療機関の選定}

個別肺がん検診実施にあたっての基本コンセプトは， 質の高い検診を維持するために日本肺癌学会編の肺癌取 扱い規約に記載されている肺癌集団検診の手引きの内容 に忠実に従って運営することである.1,2 そのためにまず 施設基準を定めた.つまり高圧撮影ができるX 線機器を 所有し，しかも診断に適する良質な胸部単純 X 線写真が 提供できることを選定基準とした.

まず平成 19 年度個別結核検診実施医療機関 154 施設 に肺癌取扱い規約に記載されている撮影装置などの規格 について説明し，次いでアンケートにて各医療機関に撮 影機器の定格, グリッドの規格, 現状の撮影条件, 使用 感光材料などの項目の質問に回答してもらった．各医療 機関に説明した規格は以下の内容であった.

1. 直接撮影の場合は, 被験者一管球管距離を $1.5 \mathrm{~m}$ 以上とし, 定格出力 $150 \mathrm{kV}$ 以上の撮影装置を用い, 120 $\mathrm{kV}$ 以上の管電圧及び希土類システム（希土類増感紙+ オルソタイプフィルム) を用いる．やむを得ず 100～ 120 $\mathrm{kV}$ の管電圧で撮影する場合も被曝軽減のために希土類 システム（希土類増感紙+オルソタイプフィルム）を用 いる.

2. デジタル撮影装置の場合は, $120 \mathrm{kV}$ 以上の管電圧 及び散乱線除去用格子比 $12: 1$ 以上を使用して撮影し, 適切な階調処理, 周波数処理, ダイナミックレンジ圧縮 処理などを施した画像として出力することが望ましい.

このアンケートの回答とともに各施設で最近撮影した
胸部 X 線写真 3 例を提出してもらい, これらの資料を新 たに編成した吹田市肺がん検診精度管理委員会で審査し た。そして選定基準に合格した施設を検診実施医療機関 として登録した. 審査に際して特に留意したのはX 線写 真を目視にて厳しく評価し，画像診断に十分に適した写 真であるかを厳密に判定した。

肺がん検診を実施するのに適合していると認定された 医療機関は 120 で,残り 34 医療機関は結核検診のみの実 施医療機関となった。 なお同時期に吹田市内の診療所な どで特定健診を実施している医療機関は178であるた め, その約 $67 \%$ の施設で個別肺がん検診が可能であると いうことであった.

この一連の申請, 審査の業務の結果をまとめてみると 以下のようになる.

・事前に必要とされる撮影条件を明示していたので申 請に関しての混乱は少なかった

・提示条件に適合できない医療機関の大半は結核検診 のみの申請をされた（肺がん検診の参加をあきらめた）

・胸部 X 線写真の画質が不適切であった施設は予想 したよりも少なかった

・デジタル撮影装置の場合は画質が不適切なものはほ とんどなかった

・肺がん検診認定施設の感光材料の内訳はレギュラー 増感紙：26, 希土類増感紙 : $66, \mathrm{CR}: 28$ であった

そして今後に向けての課題がいくつか残された.

・撮影機器, 感光材料などを変更されたときに再申請 してもらうことの周知徹底が必要

・フィルム画質が劣化したときの指導体制の構築

・デジタル撮影装置を使用している撮影医療機関で ハードコピー出力機器を保有していない施設が増加しつ つあるが, 現在の吹田市の読影システムではフィルムの みの体制であるため肺がん検診実施医療機関として参加 できない状況にある.デジタル・ソフトコピー診断にて 運営するシステムの追加導入を検討することが今後の課 題となっている

\section{2. 読影システムの構築}

診断時の偽陰性をできるだけ少なくするための二重読 影, 比較読影が的確に実施できる読影, 判定システムの 設計を行った（図 1).

一次読影は一次検診実施医療機関の医師が読影する. 受診者の以前のフィルムがあれば必ず比較読影を実施し て, 検診受診票にもそのことを記載する. 一次読影で $\mathrm{d}$, e 判定とした場合は二次読影に送らずにただちに D, E 判定に最終確定して, 要精密検査の必要性を受診者に説 明してただちに専門医療機関に紹介することにより検診 を終了する． b , c 判定とした場合は当年フィルム（過去 


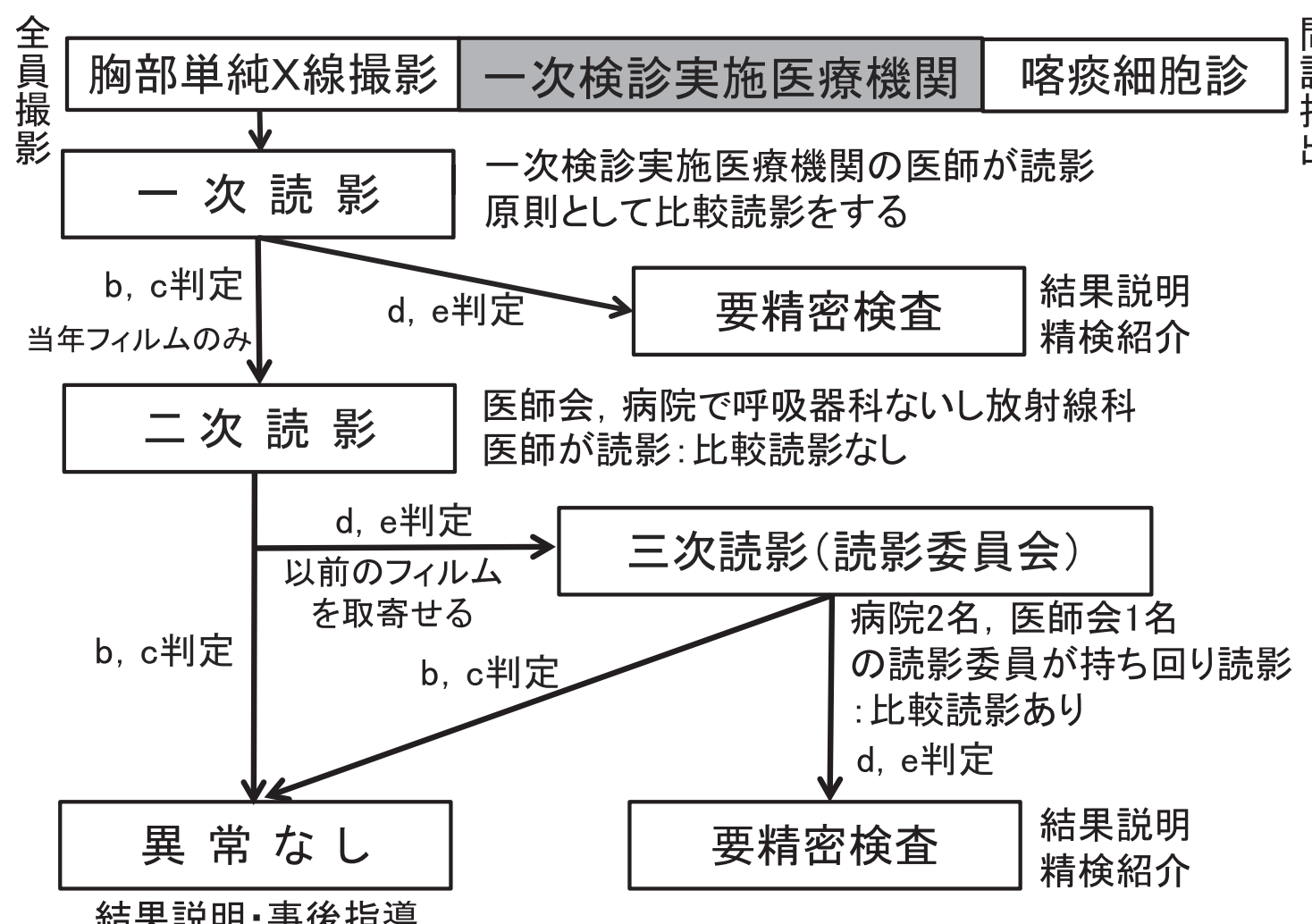

結果説明はすべて一次検診実施医療機関で行う

図1. 吹田市肺がん検診読影システム・フローチャート.

フィルムは提出しない）と受診票を吹田市立保健セン ターに搬送して, それを呼吸器科ないしは放射線科の専 門医が二次読影をする体制とした，専門医の内訳は呼吸 器科医が 8 名, 放射線科医が 3 名であり, 医師 1 人で 2 時間を 1 単位として約 200 枚の読影をしている。現状は 1 週間に 2 回の二次読影の実施で読影業務が処理できる 受診者数である.

ここまでの体制は二重読影システムとして一般的なも のであるが, 吹田市の読影システムはさらに三次読影(読 影委員会）を追加して最終決定するようにしている。 二 次読影は読影業務の煩雑さと受診者フィルムの誤認を避 けるという理由から当該年度のフィルムのみでの読影シ ステムとしている. 二次読影でも b, c 判定となった場合 はこれを最終判定として一次検診実施医療機関に結果を 記載した受診票とフィルムを返却している。d, e 判定と した場合は一次医療機関に以前のフィルムを提出する依 頼をして保健センターに過去フィルムを搬送し，三次読 影を読影委員会にて比較読影できる形で実施して最終判 定をするという方法を採用している。これにより比較読 影ができない二次読影医の負荷を軽減するようにしてい る.

図 2 が平成 21 年度の判定の内訳である。一次読影で b, c 判定となった 14,746 名が二次読影に送られた. 二次 読影で 323 名 (2.2\%) が d, e 判定となり三次読影 (読影 委員会)に送られた。次読影では 187 名 $(57.9 \%)$ がb, c 判定に戻された. 残り 136 名 (42.1\%) は d, e 判定のま まであった．三次読影では比較読影をしていることと， 複数の医師の合議で判定しているため要精密検查者とな る人数が減っていると考えている.

\section{3. 肺がん検診成績}

検診害施前後各 2 年間の吹田市肺がん検診精度管理表 （表 1）を見ると受診率は個別検診実施前 2 年間は $1.5 \%$, $1.4 \%$ であったのが 20 年度は $11.4 \%, 21$ 年度は $14.5 \%$ と 良好な結果を得ることができた．個別検診開始後の要精 検率も妥当な数值であり適切に精度管理ができていると 考える. 精検受診率は 20 年度が $85.2 \%, 21$ 年度は最終集 計ではないが $78.4 \%$ となっている. 結果説明, 事後指導 が適切に実施されていると考えているが，さらに高い精 検受診率を目指して制度設計をしていく必要があると考 えている. がん発見率も妥当な值であり, 発見肺がんの 内訳を見ても (表 2) 早期癌の比率も十分に高く, また組 織型の内訳も日本の現状に一致したものであった. ${ }^{3,4} 2$ 年間の合計 18 例のうち 14 例が一次読影で $\mathrm{d}$, e 判定と 


\section{一次読影至次読影読影委員会}

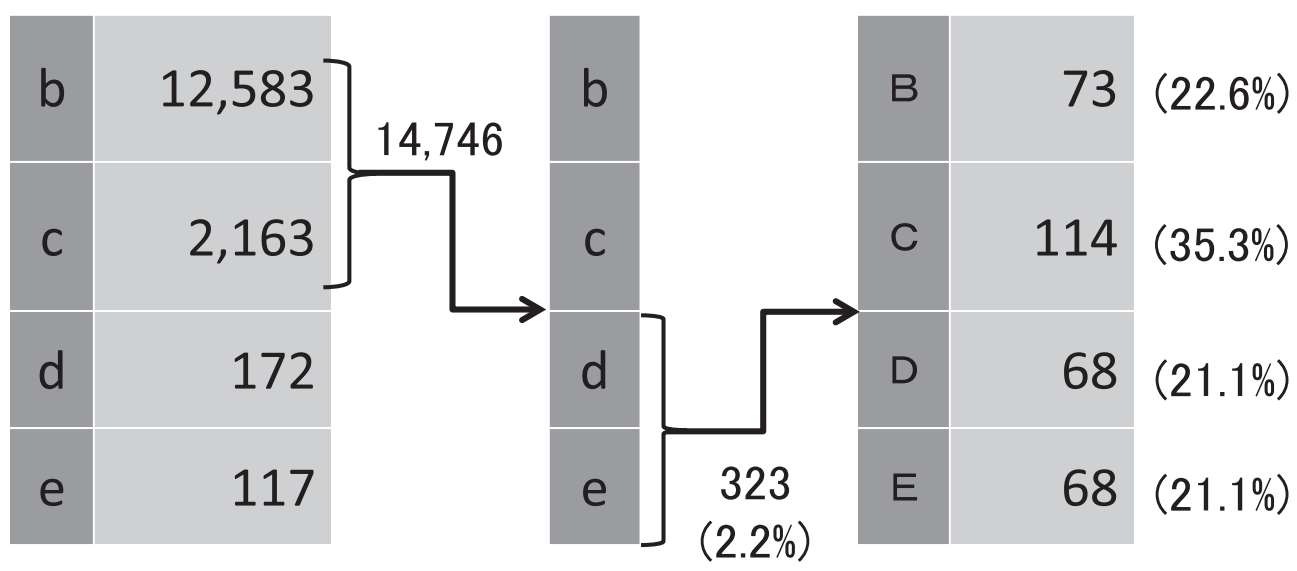

図 2. 平成 21 年度肺がん個別検診判定状況.

表 1. 肺がん検診精度管理表

\begin{tabular}{lrrrrr}
\hline & 平成 18 年度 & 平成 19 年度 & 平成 20 年度 & 平成 21 年度 \\
\hline 対象者数 & 108,266 & 109,647 & 111,542 & 113,568 \\
受診者数 & 集団検診 & 1,593 & 1,564 & 1,359 & 1,475 \\
& 個別検診 & & & 11,361 & 15,035 \\
& 計 & 1,593 & 1,564 & 12,720 & 16,510 \\
& & $1.5 \%$ & $1.4 \%$ & $11.4 \%$ & $14.5 \%$ \\
受診率 & 54 & 60 & 438 & 467 \\
要精検者数 & $3.4 \%$ & $3.8 \%$ & $3.4 \%$ & $2.8 \%$ \\
要精検率 & 46 & 57 & 373 & 366 \\
精検受診者数 & $85.2 \%$ & $95.0 \%$ & $85.2 \%$ & $78.4 \%$ \\
精検受診率 & 0 & 0 & 9 & 10 \\
発見がん & $0.00 \%$ & $0.00 \%$ & $0.07 \%$ & $0.06 \%$ \\
がん発見率 & 0 & & & \\
\hline
\end{tabular}

なっている. 一次読影は b, c 判定で二次, 三次読影にて $\mathrm{d}, \mathrm{e}$ 判定に変更されたものは 2 例に過ぎなかった。この 数值の意味する要因はいくつかあると考えられ, 今後さ らに検討していきたい.

\section{4. 精度管理}

質の高い検診システムを維持するために今後も継続し て精度管理を行っていくことが必要であり，吹田市では 以下のような取り組みをしている.

・吹田市肺がん検診精度管理委員会を最低でも年 1 回 は開催している

・一次検診実施医療機関の担当医師に吹田市肺がん検 診研修会への参加を義務付けている（年 1 回開催）

・吹田市肺がん検診仕様書を作成し, 周知徹底のため 各医療機関に対して毎年アンケートを実施して確認して いる

・二次, 三次読影医は読影時に常にX 線写真の画質に
注意を払い, 撮影条件, 現像処理などに問題点があると 判断したときは, 該当撮影医療機関に対して撮影の技術 的アドバイスを行い注意喚起している

\section{おわりに}

地域の診療所の X 線装置の性能はさまざまであり, 個 別肺がん検診を実施するにあたっての最大の課題は診断 に適する品質の胸部単純 X 線写真を確保できるかとい うことにあった. 約 20 年前にも個別肺がん検診実施を目 指して基礎調查を行ったことがあるが, 半数以上の施設 で高圧撮影が実施できないという事害が判明して個別検 診を断念した経緯がある.それが 20 年を経て行った今回 のアンケート調查の結果, 約 $2 / 3$ の施設で肺がん検診が 実施可能であったということで診療所が保有する機器性 能の進歩を知り, 改めて時代の流れを感じた. 都市型地 域で住民に向けての受診率向上のためのアプローチは個 別検診が最も有効であるということを吹田市では以前か 
表 2. 発見肺がん内訳

\begin{tabular}{ccccccccc}
\hline \multicolumn{1}{l}{ 平成 20 年度 } & \multicolumn{10}{c}{} \\
\hline & 年齢 & 性 & 診断名 & 臨床病期 & 組織型 & X 線一次判定 & X 線最終判定 & 喀痰判定 \\
\hline 1 & 59 & 女 & 原発性肺がん & IA & 腺がん & $\mathrm{d}$ & $\mathrm{D}$ & - \\
2 & 61 & 女 & 原発性肺がん & IB & 腺がん & $\mathrm{d}$ & $\mathrm{D}$ & - \\
3 & 62 & 女 & 原発性肺がん & IIIA & 腺がん & $\mathrm{d}$ & $\mathrm{D}$ & - \\
4 & 62 & 男 & 原発性肺がん & IV & 腺がん & $\mathrm{d}$ & $\mathrm{D}$ & $\mathrm{B}$ \\
5 & 71 & 女 & 原発性肺がん & IV & 腺がん (脳転移) & $\mathrm{d}$ & $\mathrm{D}$ & - \\
6 & 69 & 男 & 原発性肺がん & IIIA & 腺がん & $\mathrm{e}$ & $\mathrm{E}$ & - \\
7 & 51 & 男 & 原発性肺がん & III & 腺がん & $\mathrm{e}$ & $\mathrm{E}$ & - \\
8 & 62 & 男 & 原発性肺がん & IA & 扁平上皮がん & $\mathrm{b}$ & $\mathrm{B}$ & $\mathrm{C}$ \\
\hline
\end{tabular}

平成 21 年度

\begin{tabular}{|c|c|c|c|c|c|c|c|c|}
\hline & 年齢 & 性 & 診断名 & 臨床病期 & 組織型 & X 線一次判定 & X 線最終判定 & 喀痰判定 \\
\hline 1 & 61 & 女 & 原発性肺がん & IA & 腺がん & $\mathrm{c}$ & $\mathrm{D}$ & - \\
\hline 2 & 72 & 男 & 原発性肺がん & IIIA & 扁平上皮がん & $\mathrm{c}$ & $\mathrm{E}$ & - \\
\hline 3 & 64 & 女 & 原発性肺がん & IA & 腺がん & $\mathrm{d}$ & $\mathrm{D}$ & - \\
\hline 4 & 73 & 男 & 原発性肺がん & IA & 扁平上皮がん & e & $\mathrm{E}$ & $\mathrm{D}$ \\
\hline 5 & 69 & 男 & 原発性肺がん & IA & 腺がん & e & $\mathrm{E}$ & - \\
\hline 6 & 80 & 女 & 原発性肺がん & IV & 腺がん & e & $\mathrm{E}$ & - \\
\hline 7 & 61 & 女 & 原発性肺がん & IA & 腺がん & e & $\mathrm{E}$ & - \\
\hline 8 & 67 & 男 & 原発性肺がん & IIA & 腺がん & e & $\mathrm{E}$ & - \\
\hline 9 & 60 & 男 & 原発性肺がん & IV & 扁平上皮がん & e & $\mathrm{E}$ & - \\
\hline 10 & 78 & 男 & 原発性肺がん & $\mathrm{LD}$ & 小細胞がん & $\mathrm{c}$ & B & $\mathrm{D}$ \\
\hline
\end{tabular}

ら理解していて, その推進に積極的に取り組んでいる. その成果と思われるが, 以前の基本健康診査，現在の特 定健診ともに受診率は大阪府下で常にトップを争う順位 にあり，子宮がん検診，乳がん検診，大腸がん検診も都 市部としては優秀な受診率を維持している．肺がん検診 もようやく個別検診を始めることができたが，十分に精 度管理された検診を行うことでのみ有効性が認められる という事実があるので，今後とも精度管理のためのさま ざまな取り組みをしていく必要があると考えている.

本論文内容に関連する著者の利益相反：なし

謝辞：個別肺がん検診の運営に多大なご協力をいただいてい
る吹田市立保健センター, 吹田市医師会事務局, 済生会吹田病 院, 済生会千里病院, 市立吹田市民病院, 一般財団法人阪大微 生物病研究会の皆様に深謝いたします。

\section{REFERENCES}

1. 肺癌集団検診の手引. 日本肺癌学会, 編集. 肺癌取扱い規 約. 改訂第 7 版. 東京 : 金原出版 ; 2010:180-197.

2. 田中絵里子, 薄井庸平, 藤澤英文. CT 肺がん検診. 櫛橋 民生, 野口雅之, 編著. 肺癌の画像診断と病理. 東京 : 中 外医学社；2008:165-175.

3. 富田弘志, 池田留美, 長田智貴, 早田 宏, 河野 茂. 長 崎県における肺癌検診の現況と問題点. 肺癌. 2010;50: 194-200.

4. 中山富雄, 鈴木隆一郎, 楠 洋子. 肺癌検診の精度管理の 方向性一大阪府の試み一. 肺癌. 2010;50:201-205. 